\title{
Pleurotus ostreatus Laccase Decolorization of Remazol Brilliant Violet 5R Dye: Statistical Optimization and Toxicity Studies on Microbes and its Kinetics
}

\author{
Preethi Thozhukattu Valliyaparambil', Kathireshan Alagapuram Kaliyaperumal', Narendrakumar Gopakumaran ${ }^{2^{*}}$ \\ ${ }^{1}$ Department of Microbiology, School of Life Science, Vels Institute of Science, Technology and Advance Studies, Pallavaram, Chennai \\ - 600 117, Tamilnadu, India \\ ${ }^{2}$ Department of Biotechnology, School of Bio and Chemical Engineering, Sathyabama Institute of Science and Technology, Chennai \\ - 600 119, Tamilnadu, India
}

Corresponding Author: Narendrakumar Gopakumaran, Department of Biotechnology, School of Bio and Chemical Engineering, Sathyabama Institute of Science and Technology, Chennai - 600 119, Tamilnadu, India. Email: gnaren22@gmail.com

Received June 1, 2019; Accepted July 15, 2019; Online Published September 11, 2019

\begin{abstract}
Introduction: Nowadays, enzyme-based removal of hazardous dyes that pollute the environment has been considered as a substitute and ecofriendly method compared to the physical and chemical method. The present study was conceived in order to obtain the optimal condition for laccase-mediated (purified from the Pleurotus ostreatus PKN04) decolorization of Remazol Brilliant Violet 5R dye; a mono-azo dye, using the central composite design of response surface methodology (RSM).

Materials and Methods: The design of experiment was suggested with 6 variables including $\mathrm{pH}$, temperature, incubation time, agitation, dye concentration, and enzyme concentration, which were applied in order to optimize the decolorization process. The kinetic and energetic factors of laccases for the enzymatic removal of Remazol Brilliant Violet $5 R$ dye was investigated.

Results: Decolorization of Remazol Brilliant Violet $5 \mathrm{R}$ was maximally $95.72 \%$, which had occurred at $6.0 \mathrm{pH}, 40^{\circ} \mathrm{C}$ temperature, 60 minutes incubation time, $50 \mathrm{rpm}$ agitation, $50 \mathrm{ppm}$ dye concentration, and $100 \mathrm{IU} / \mathrm{mL}$ enzyme concentration. The obtained results of kinetic introduced the laccase-catalyzed decolorization of Remazol Brilliant Violet $5 \mathrm{R}$ as an endothermic reaction with $\mathrm{K}_{\mathrm{m}}$ and $\mathrm{V}_{\max }$ values of $0.801 \mathrm{mM}$ and $387 \mathrm{mM} /$ $\mathrm{mg} / \mathrm{min}$, respectively. In addition to the above results, the toxicity study against bacteria revealed that the toxicity of laccase-treated dye drastically reduced to the untreated dye.

Conclusions: The results of the present analysis reveal that the Pleurotus ostreatus laccase is an efficient biocatalyst for decolorization of synthetic dye Remazol Brilliant Violet 5R dye.

Keywords: Enzyme Catalysis, Optimization, Response Surface Methodology, Central Composite Design, Decolorization, Laccase

Citation: Valliyaparambil PT, Kaliyaperumal KA, Gopakumaran N. Pleurotus ostreatus laccase decolorization of Remazol Brilliant Violet 5R dye: statistical optimization and toxicity studies on microbes and its kinetics. J Appl Biotechnol Rep. 2019;6(3):88-95. doi:10.29252/JABR.06.03.02.
\end{abstract}

\section{Introduction}

White-rot basidiomycetes are the most effective microorganisms to decolorize and degrade a wide range of dyes and pollutants. These fungi specifically attack ligninolytic compounds by producing oxidative enzymes, namely the peroxidases and laccases. ${ }^{1}$ Laccase (benzenediol: oxygen oxidoreductase, EC 1.10.3.2) are a small collection of enzymes called the blue copper proteins or the blue copper oxidases along with the plant ascorbate oxidase and the mammalian plasma protein ceruloplasmin ${ }^{3,4}$ among others. Laccase is an enzyme secreted by many of the lignin degrading basidiomycetes and has been reported as an essential enzyme for lignin degradation in fungi without per-oxidases. ${ }^{5}$ This enzyme catalyzes the oxidation of a wide number of phenolic compounds and aromatic amines but its substrate range have been extended to non-phenolic compounds in the presence of low molecular mass compounds acting as mediators. ${ }^{6,7}$
Most of the studies have been carried out with laccases from eukaryotes, principally with enzymes secreted by basidiomycetes being their distribution in prokaryotes more recently. Different industrial purposes for fungal laccases have been insinuated and they include paper processing, inhibition of wine decolouration, detoxification of ecological pollutants, oxidation of dye and their precursors, enzymatic translation of chemical intermediates, and production of chemicals from lignin. Before laccases can be commercially employed for potential applications, however, an inexpensive enzyme source needs to be made available. ${ }^{8-10}$ Two of the most intensively studied areas in the potential industrial application of laccase are the delignification and pulp bleaching and the bioremediation of contaminating environmental pollutants. ${ }^{11}$

The response surface methodology (RSM) which is broadly utilized in optimization processes, implicates a compilation of useful mathematical and statistical skills for analyzing the

Copyright (C) 2019 The Author(s). This is an open-access article distributed under the terms of the Creative Commons Attribution License (http:// creativecommons.org/licenses/by/4.0), which permits unrestricted use, distribution, and reproduction in any medium, provided the original work is properly cited. 
relationship between independent variables, responses, and their interactions through the construction of polynomial mathematical models which leads to time and cost saving. ${ }^{12-14}$ In the present study, a central composite design of RSM as a very suitable design method was employed to acquire maximal removal of Remazol Brilliant Violet 5R dye supported by laccase. The kinetic parameters of laccasefacilitated dye removal process were investigated. The toxicity against different bacterial experiments were also instigated in order to assess the toxicity of laccase degraded dye.

\section{Materials and Methods}

Chemicals

Remazol Brilliant Violet-5R (RBV-5R) $\mathrm{C}_{20} \mathrm{H}_{16} \mathrm{~N}_{3} \mathrm{Na}_{3} \mathrm{O}_{15} \mathrm{~S}_{4}$ Molecular weight 735.58 and $\lambda_{\text {max }}$ of $570 \mathrm{~nm}, 2$,2'-Azino-bis(3ethylbenzthiazoline-6-sulphonate) (ABTS) was purchased from Sigma-Aldrich (Bangalore, India). All chemicals and reagents had analytical grade purity. The extracellular laccase of Pleurotus ostreatus PKN04 was purified using various methods. ${ }^{15}$

\section{Organism}

Pleurotus ostreatus PKN 04 was isolated from the decomposed wood and leaf litters of Chennai forest and grown in Sabouraud dextrose agar (SDA). The organism was screened for the production of laccase by ABTS method, subcultured to obtain pure culture and identified using $18 \mathrm{~s}$ rRNA sequencing method. ${ }^{16}$

Pleurotus ostreatus PKN 04 was grown in Malt Extract Medium (MEA) and the spores were washed and inoculated in the fermentation medium. ${ }^{17}$

\section{Analysis of Enzyme Activity}

The activity of the free laccase was assayed using $1 \mathrm{mM}$ ABTS in distilled water as substrate. The reaction mixture consisting of $3 \mathrm{~mL}$ of $0.1 \mathrm{M}$ acetate buffer, $4.5 \mathrm{pH}$ containing enzyme was initiated by adding $0.3 \mathrm{~mL}$ of ABTS. Free enzyme by the addition of 10 seconds intervals at $420 \mathrm{~nm}$ Cary Varian UV/VIS absorbance measurements were taken by spectrophotometer. Ten beads, $2.7 \mathrm{~mL}$ acetate buffer and $0.3 \mathrm{~mL}$ of ABTS were incubated with shaking at $100 \mathrm{rpm}$ for 5 minutes for immobilization laccase activity. To separate the beads at the end, the upper phase at $570 \mathrm{~nm}$ absorbance was measured. One activity unit of laccase was defined as the amount of enzyme required to catalyze $1 \mathrm{mmol} / \mathrm{mL}$ of substrate per minute. ${ }^{18,19}$

\section{Dye Decolorization Experiments}

After preparation of dye solution (concentration range of $50-150 \mathrm{mg} / \mathrm{L})$ in citrate-phosphate buffer $(0.1 \mathrm{M}, \mathrm{pH}$ range of 3.0-8.0), the partially purified laccases (final activity of $1-2.5 \mathrm{U} / \mathrm{L}$ ) were added to the reaction mixture and incubated at desired temperature $\left(30-50^{\circ} \mathrm{C}\right)$ for $30-90$ minutes. It was followed by measuring the absorbance of the taken samples using a UV/visible spectrophotometer at maximum absorbance of applied dye $(570 \mathrm{~nm}) .^{20}$

Decolorization percentage was then calculated using the following equation:

Decolorization $=\frac{\left(A_{i}-A_{t}\right)}{A_{i}} \times 100$

$A_{i}$ is the initial absorbance of the reaction mixture and at is the absorbance after incubation time. The reaction mixture with the heat-inactivated enzyme was formulated (negative control) and incubated at similar conditions. All trails were performed in duplicates and the means of decolorization percentages were reported.

\section{Response Surface Methodology}

The central composite design has been developed to select the design points as the design of experiments (Table 1) that minimizes the related variances and analyzed using FT-IR. ${ }^{21}$

\section{Dye Removal Kinetics}

\section{Kinetics of Decolorization}

After performing decolorization in the presence of different concentrations of dye $(10-500 \mu \mathrm{M})$ at an ideal temperature and $\mathrm{pH}$, the velocity for different concentrations of dye were determined. The MM curve was then drawn by plotting the attained initial velocity verses dye concentrations. Calculation of $\mathrm{K}_{\mathrm{m}}$ and $\mathrm{V}_{\max }$ values were performed by fitting the data to the Lineweaver-Burk plot, resulting of the Michaelis-Menten plot conversion using Hyper 32 software. ${ }^{22-25}$

\section{Toxicity Studies on Microbes}

A series of testing were performed to evaluate toxicity of the synthesized metabolite following laccase therapy. The preincubated bacterial culture Staphylococcus aureus MTCC 740, Bacillus subtilis MTCC 441 and E. coli MTCC 443, Pseudomonas aeruginosa MTCC 741, and Salmonella typhi MTCC 3124 was prepared by incubating each bacterial strain in Muller-Hinton broth at $37^{\circ} \mathrm{C}$ and $150 \mathrm{rpm}$ to reach the $\mathrm{OD}_{620}$ of 0.2. Consequently, the untreated dye solution (final concentration of $100 \mathrm{mg} / \mathrm{L}$ ) and the sample obtained from enzymatic treatment of applied dye (performed at the

Table 1. Design of Experiment

\begin{tabular}{|c|c|c|c|c|c|c|}
\hline \multirow{2}{*}{ Factor } & \multicolumn{2}{|c|}{ Low } & \multicolumn{2}{|c|}{ High } & \multirow{2}{*}{ Mean } & \multirow{2}{*}{ SD } \\
\hline & Coded & Actual & Coded & Actual & & \\
\hline $\mathrm{A}-\mathrm{pH}$ & -1 & 4 & 1 & 8 & 6 & 1.790141 \\
\hline C - Incubation Time & -1 & 30 & 1 & 90 & 60 & 26.85211 \\
\hline D - Agitation & -1 & 0 & 1 & 100 & 50 & 44.75352 \\
\hline E - Dye concentration & -1 & 50 & 1 & 150 & 100 & 44.75352 \\
\hline
\end{tabular}


optimized condition) was separately added to the prepared bacterial culture media and incubated at $37^{\circ} \mathrm{C}$. Changes in the $\mathrm{OD}_{620}$ of each bacterial strain were then recorded every 2 hours for 10 hours. A negative control (cultivated bacterial strain in the absence of dye) was designed for each experiment. ${ }^{26,27}$

The precentage of grwoth inhibition $=\frac{\left(1-O D_{620} \text { Sample }\right)}{O D_{620} \text { Control }}$

\section{Statistical Analysis}

The data were obtained from duplicate experiments unless mentioned particularly and the experimental results were expressed as mean \pm standard deviation.

\section{Results and Discussion}

Isolation and Identification of Organism

The isolated organism was identified using the macroscopic and microscopic method. The microscopic features are as follows: spores $8-10.5 \times 3-3.5 \mu$; smooth; cylindrical to narrowly kidney-shaped may be an epitype collection of Pleurotus ostreatus PKN04. ${ }^{28}$

Optimization of Factors using Response Surface Methodology Optimization was done using the Central Composite Design (CCD). Results show significance as the $\mathrm{R}^{2}$ value and the $\mathrm{R}^{2}$ adjusted value are close enough and the error ration is less than 0.05 . The interaction of the variables was shown in Figure 1. The statistical outcomes (actual and predicted results) for the ideal equation was displayed in Table 2. The F value quantifies the difference of the data about the mean. Also, the $P$ value functions as a tool for examining the importance of every coefficient. The predicted $\mathrm{R}^{2}$ value is logically accord to

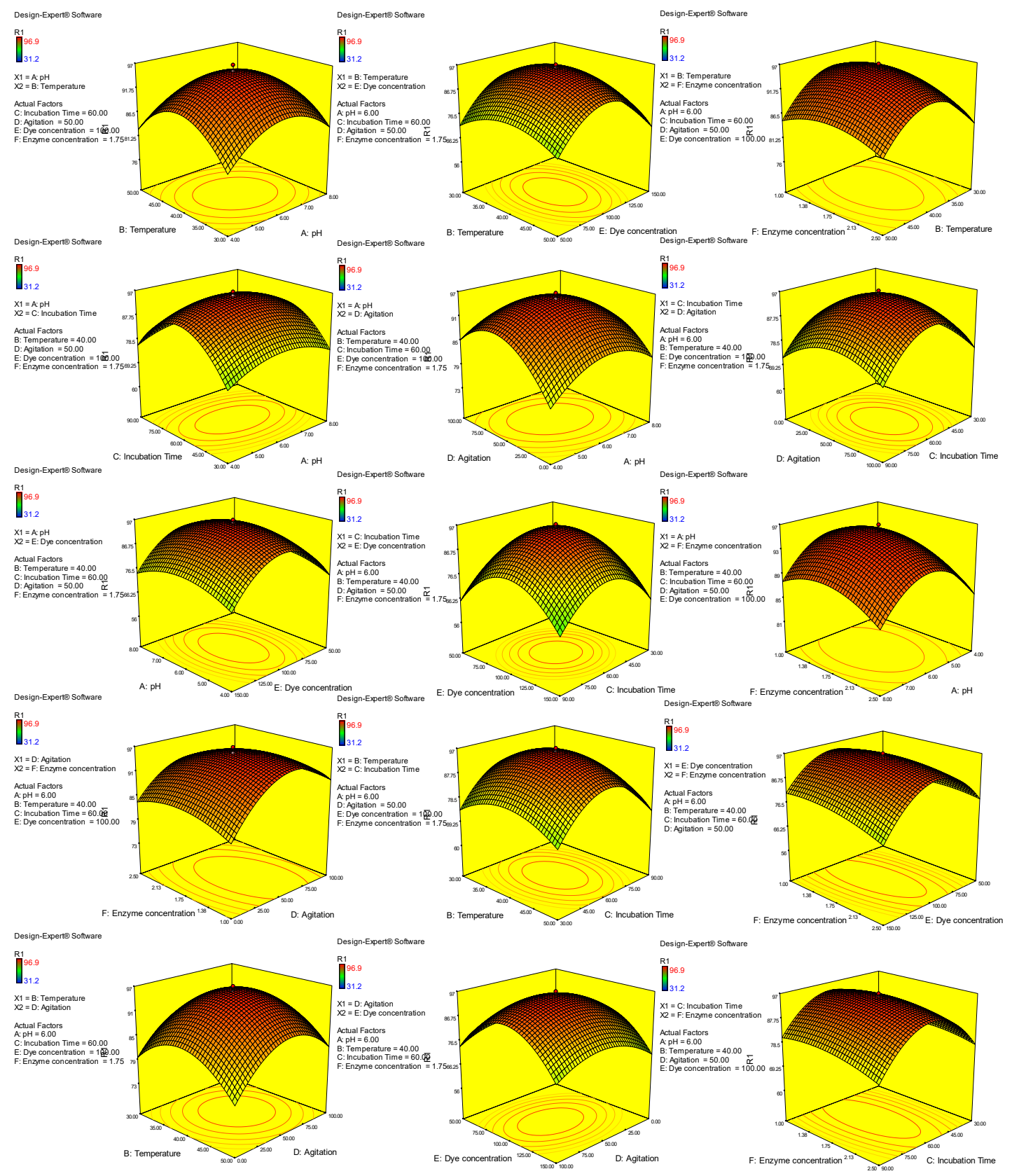

Figure 1. RSM Contour Plot and Surface Plot for Different Parameters $(A B, A C, A D, A E, A F, B C, B D, B E, B F, C D, C E, C F, D E, D F, E F)$. 
Table 2. Central Composite Design Matrix (CCD) and Their Observed Responses for Laccase-Assisted Decolorization of Remazol Brilliant Violet-5R

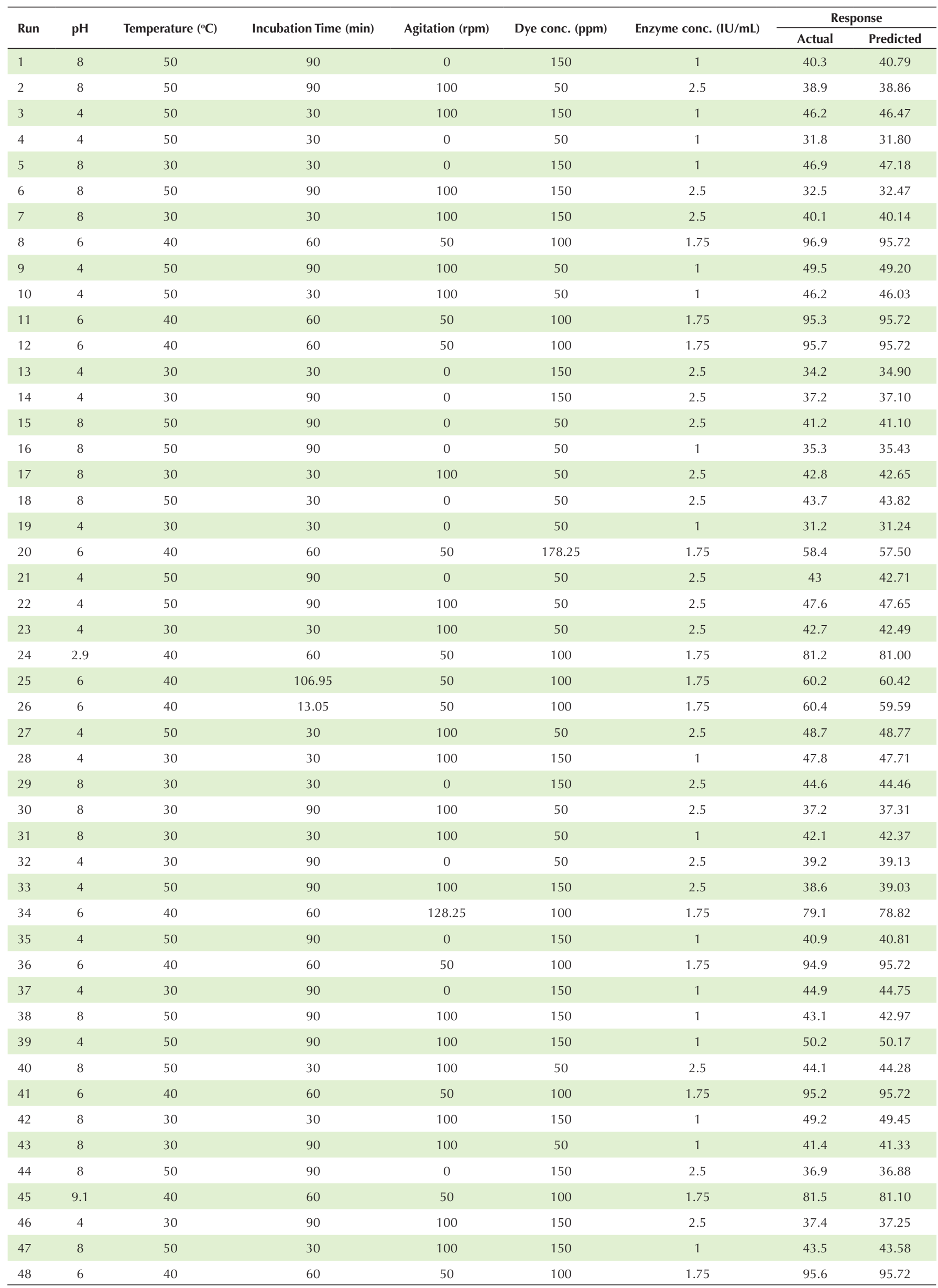


Table 2. Continued

\begin{tabular}{|c|c|c|c|c|c|c|c|c|}
\hline \multirow{2}{*}{ Run } & \multirow{2}{*}{$\mathrm{pH}$} & \multirow{2}{*}{ Temperature $\left({ }^{\circ} \mathrm{C}\right)$} & \multirow{2}{*}{ Incubation Time (min) } & \multirow{2}{*}{ Agitation (rpm) } & \multirow{2}{*}{ Dye conc. (ppm) } & \multirow{2}{*}{ Enzyme conc. (IU/mL) } & \multicolumn{2}{|c|}{ Response } \\
\hline & & & & & & & Actual & Predicted \\
\hline 49 & 6 & 24.35 & 60 & 50 & 100 & 1.75 & 78.7 & 78.40 \\
\hline 50 & 4 & 50 & 30 & 0 & 50 & 2.5 & 41.1 & 41.13 \\
\hline 51 & 4 & 50 & 30 & 100 & 150 & 2.5 & 39.4 & 39.62 \\
\hline 52 & 4 & 30 & 90 & 0 & 50 & 1 & 37.1 & 37.20 \\
\hline 53 & 4 & 30 & 90 & 100 & 50 & 1 & 45.5 & 46.11 \\
\hline 54 & 8 & 30 & 90 & 0 & 50 & 2.5 & 41.9 & 42.16 \\
\hline 55 & 4 & 30 & 30 & 100 & 50 & 1 & 42.9 & 42.86 \\
\hline 56 & 8 & 30 & 90 & 100 & 150 & 2.5 & 35.2 & 35.33 \\
\hline 57 & 8 & 30 & 90 & 0 & 150 & 1 & 49.2 & 49.37 \\
\hline 58 & 6 & 40 & 60 & -28.25 & 100 & 1.75 & 73.5 & 73.18 \\
\hline 59 & 6 & 55.65 & 60 & 50 & 100 & 1.75 & 76.9 & 76.60 \\
\hline 60 & 4 & 30 & 30 & 0 & 50 & 2.5 & 37.5 & 37.46 \\
\hline 61 & 8 & 30 & 30 & 0 & 50 & 2.5 & 44.5 & 44.79 \\
\hline 62 & 6 & 40 & 60 & 50 & 100 & 2.92 & 87.5 & 86.98 \\
\hline 63 & 6 & 40 & 60 & 50 & 21.75 & 1.75 & 56.7 & 57.00 \\
\hline 64 & 8 & 30 & 30 & 0 & 50 & 1 & 38.4 & 37.93 \\
\hline 65 & 8 & 50 & 30 & 0 & 150 & 2.5 & 39.2 & 39.07 \\
\hline 66 & 6 & 40 & 60 & 50 & 100 & 0.58 & 90.4 & 90.33 \\
\hline 67 & 6 & 40 & 60 & 50 & 100 & 1.75 & 95.5 & 95.72 \\
\hline 68 & 8 & 50 & 30 & 100 & 150 & 2.5 & 37.3 & 37.36 \\
\hline 69 & 8 & 50 & 30 & 100 & 50 & 1 & 40.9 & 40.91 \\
\hline 70 & 4 & 50 & 90 & 0 & 50 & 1 & 37.5 & 37.67 \\
\hline 71 & 4 & 50 & 30 & 0 & 150 & 1 & 34.5 & 34.42 \\
\hline 72 & 8 & 50 & 30 & 0 & 50 & 1 & 33.5 & 33.86 \\
\hline 73 & 8 & 30 & 90 & 100 & 150 & 1 & 48.9 & 48.93 \\
\hline 74 & 4 & 30 & 30 & 0 & 150 & 1 & 38.2 & 38.27 \\
\hline 75 & 8 & 30 & 90 & 0 & 150 & 2.5 & 42.3 & 42.35 \\
\hline 76 & 8 & 50 & 30 & 0 & 150 & 1 & 38.9 & 38.70 \\
\hline 77 & 6 & 40 & 60 & 50 & 100 & 1.75 & 94.9 & 95.72 \\
\hline 78 & 8 & 50 & 90 & 100 & 50 & 1 & 40.1 & 39.78 \\
\hline 79 & 4 & 50 & 30 & 0 & 150 & 2.5 & 34.2 & 34.15 \\
\hline 80 & 8 & 30 & 90 & 0 & 50 & 1 & 40.2 & 39.59 \\
\hline 81 & 6 & 40 & 60 & 50 & 100 & 1.75 & 95.5 & 95.72 \\
\hline 82 & 4 & 30 & 90 & 100 & 50 & 2.5 & 41.6 & 41.46 \\
\hline 83 & 4 & 50 & 90 & 0 & 150 & 2.5 & 36.2 & 36.26 \\
\hline 84 & 4 & 30 & 30 & 100 & 150 & 2.5 & 37.8 & 37.76 \\
\hline 85 & 4 & 30 & 90 & 100 & 150 & 1 & 51.7 & 51.49 \\
\hline 86 & 6 & 40 & 60 & 50 & 100 & 1.75 & 95.6 & 95.72 \\
\hline
\end{tabular}

the adjusted $\mathrm{R}^{2}$ value. The $\mathrm{R}^{2}$ value of the enzyme activity was 0.995 that ensures the reasonable adjustment of the quadratic model to the experimental model (Table 3 ).

Response $=95.722+0.033 \mathrm{~A}-0.575 \mathrm{~B}+0.265 \mathrm{C}+1.802 \mathrm{D}+$ $0.157 \mathrm{E}-1.070 \mathrm{~F}-1.159 \mathrm{AB}-1.075 \mathrm{AC}-1.793 \mathrm{AD}+0.5562 \mathrm{AE}$ $+0.159 \mathrm{AF}-0.021 \mathrm{BC}+0.653 \mathrm{BD}-1.103 \mathrm{BE}+0.775 \mathrm{BF}-0.675$ $\mathrm{CD}+0.131 \mathrm{CE}-1.0718 \mathrm{CF}-0.543 \mathrm{DE}-1.647 \mathrm{DF}-2.3968 \mathrm{EF}$ $-5.989 \mathrm{~A}^{2}-7.4388 \mathrm{~B}^{2}-14.5832 \mathrm{C}^{2}-8.0512 \mathrm{D}^{2}-15.706 \mathrm{E}^{2}-2.886$ $\mathrm{F}^{2}$
Validation of Model

In order to determine the correctness of the model, three verification experiments were performed using the statistically optimal requirements. The results showed a maximum decolorization efficiency of $95.7 \%$, which is about $94.2 \%$ of the predicted value, implying a strong similarity between experimental and predicted values calculated from the model that confirms the precision and validity of the model. ${ }^{29}$ 
Table 3. Analysis of Variance

\begin{tabular}{|c|c|c|c|c|c|}
\hline Source & Sum of Squares & $d f$ & Mean Square & F Value & $\begin{array}{c}\text { PValue } \\
\text { Prob }>F\end{array}$ \\
\hline Model & 35303.96 & 27 & 1307.554 & 8319.461 & $<0.0001$ \\
\hline A- $p H$ & 0.074758 & 1 & 0.074758 & 0.475656 & 0.4931 \\
\hline B- Temperature & 22.78 & 1 & 22.78 & 144.9403 & $<0.0001$ \\
\hline C- Incubation Time & 4.853682 & 1 & 4.853682 & 30.8821 & $<0.0001$ \\
\hline D- Agitation & 223.7597 & 1 & 223.7597 & 1423.697 & $<0.0001$ \\
\hline E- Dye concentration & 1.711979 & 1 & 1.711979 & 10.89266 & 0.0017 \\
\hline F- Enzyme concentration & 78.91848 & 1 & 78.91848 & 502.1278 & $<0.0001$ \\
\hline$A B$ & 86.02562 & 1 & 86.02562 & 547.3478 & $<0.0001$ \\
\hline $\mathrm{AC}$ & 73.96 & 1 & 73.96 & 470.5789 & $<0.0001$ \\
\hline$A D$ & 205.9225 & 1 & 205.9225 & 1310.205 & $<0.0001$ \\
\hline $\mathrm{AE}$ & 19.8025 & 1 & 19.8025 & 125.9957 & $<0.0001$ \\
\hline $\mathrm{AF}$ & 1.625625 & 1 & 1.625625 & 10.34322 & 0.0021 \\
\hline $\mathrm{BC}$ & 0.030625 & 1 & 0.030625 & 0.194855 & 0.6605 \\
\hline $\mathrm{BD}$ & 27.30062 & 1 & 27.30062 & 173.7033 & $<0.0001$ \\
\hline $\mathrm{BE}$ & 77.88062 & 1 & 77.88062 & 495.5243 & $<0.0001$ \\
\hline $\mathrm{BF}$ & 38.44 & 1 & 38.44 & 244.5789 & $<0.0001$ \\
\hline $\mathrm{CD}$ & 29.16 & 1 & 29.16 & 185.5338 & $<0.0001$ \\
\hline CE & 1.1025 & 1 & 1.1025 & 7.014781 & 0.0104 \\
\hline $\mathrm{CF}$ & 73.53062 & 1 & 73.53062 & 467.8469 & $<0.0001$ \\
\hline $\mathrm{DE}$ & 18.9225 & 1 & 18.9225 & 120.3966 & $<0.0001$ \\
\hline DF & 173.5806 & 1 & 173.5806 & 1104.426 & $<0.0001$ \\
\hline $\mathrm{EF}$ & 367.6806 & 1 & 367.6806 & 2339.41 & $<0.0001$ \\
\hline$C^{2}$ & 2953.093 & 1 & 2953.093 & 18789.39 & $<0.0001$ \\
\hline $\mathrm{D}^{2}$ & 900.1118 & 1 & 900.1118 & 5727.063 & $<0.0001$ \\
\hline$E^{2}$ & 3425.28 & 1 & 3425.28 & 21793.73 & $<0.0001$ \\
\hline$F^{2}$ & 115.7271 & 1 & 115.7271 & 736.3266 & $<0.0001$ \\
\hline Residual & 9.115751 & 58 & 0.157168 & & \\
\hline Lack of Fit & 6.246751 & 49 & 0.127485 & 0.399917 & 0.9807 \\
\hline Pure Error & 2.869 & 9 & 0.318778 & & \\
\hline Cor Total & 35313.08 & 85 & & & \\
\hline
\end{tabular}

Standard deviation =0.396444; Mean=51.93488; C.V. \% =0.763349; PRESS=20.45463; R-Squared=0.99742; Adjusted R-Squared=0.99622; Predicted R-Squared= 0.99421; Adeq Precision=285.0496.

Dye Toxicity

The obtained results of toxicity evaluation of untreated and laccase-treated dye solution showed that when Remazol Brilliant Violet 5R dye was used, the calculated growth inhibition (\%) in the presence S. aureus MTCC 740, and B. subtilis MTCC 441 and E. coli MTCC 443, P. aeruginosa MTCC 741, and S. typhi MTCC 312 was found to be $72 \pm 2.9$, $68.5 \pm 3.5,68.9 \pm 6.1,52.6 \pm 4.3$ and $62.8 \pm 6.3$ respectively. However, the growth inhibition (\%) for laccase treated dye solution was $35 \pm 1.2,28.5 \pm 1.7,29.9 \pm 0.9,32.5 \pm 2.1$ and $39.1 \pm 1.3$ respectively, that shows an effective reduction of toxicity. ${ }^{30}$

\section{Enzyme Kinetics}

The linear association among the initial velocity and dye concentration indicated that the decolorization is a first order reaction. Based on the MM and LB plots for enzymatic decolorization of Remazol Brilliant Violet 5R showed that $\mathrm{V}_{\max }$ was 387 and the $\mathrm{K}_{\mathrm{m}}$ value was 0.801 . The Lineweaver Burk plot and Hans plot were also established for the reactions with the same values. The parameter space plot suggests the possible condition of reactions (Figure 2).

FT-IR Analysis

The efficacy of the degradation was studied using FT-IR. The peaks present in the graph got deteriorated after the dye was subjected to decolourisation. The FT-IR spectra of the adsorbents display the number of adsorption peaks, indicating the complex nature of the studied adsorbents. In FT-IR analysis, several peaks were observed in the spectra 


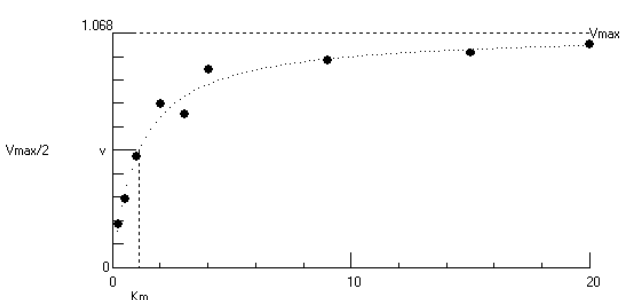

(A) [s]

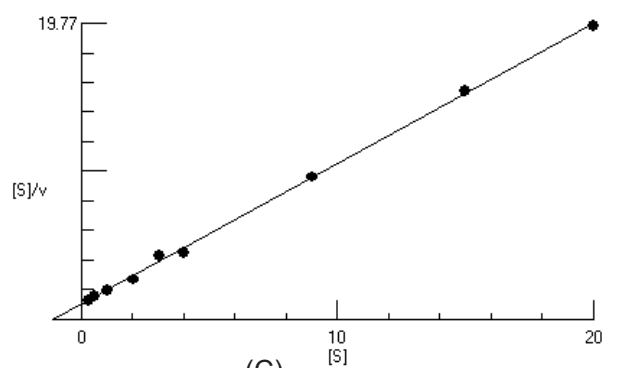

(C)
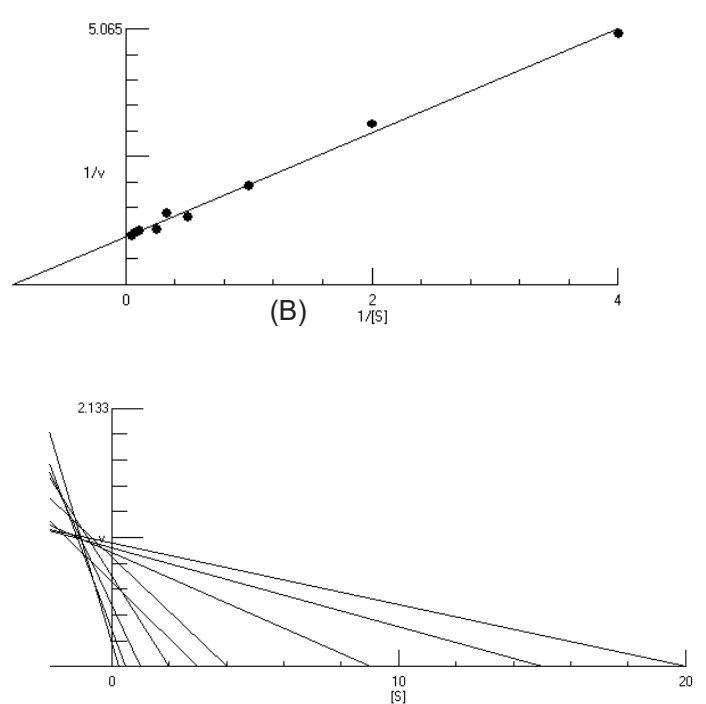

(D)

Figure 2. Kinetics study. (A) Michaelis-Menten plot. (B) Lineweaver-Burk plot.(C) Hans Plot. (D) Parameter space plot.

which indicated that the adsorbent is composed of various functional groups which are responsible for binding the chitosan. The bands 2083.2 and 2090.5 shows the variation in nitrile group $(-\mathrm{C}=\mathrm{N})$, the peaks 1640.8 and 1635.8 shows the variation in alkene groups $(\mathrm{C}=\mathrm{C})$ and the peaks 676 and 684.2 shows the variation in carbonyl group $(\mathrm{C}=\mathrm{O}){ }^{32-34}$

There was significant variation in the peak before and after adsorption, which meaning that the high peak bond is stronger, so adsorption is more comparatively than the lower one (Figure 3). The deformation of $\mathrm{OH}$ and $\mathrm{NH}$ groups at the peaks $3700-3000 \mathrm{~cm}^{-1}$.

\section{Conclusions}

The laccase enzyme production by P. ostreatus PKN04 was successfully optimized through the application of RSMCCD to achieve the maximum favorable cultural conditions for laccase based decolorization process. Quadratic model was formed using 6 factors in terms of $\mathrm{pH}$, temperature, incubation time, agitation, dye concentration, and enzyme concentration to epitomize the activity of laccase. The coefficients of independent variables were calculated using Design Expert 7.0. Decolorization of Remazol Brilliant Violet $5 \mathrm{R}$ was maximally $95.72 \%$, which had occurred at $6.0 \mathrm{pH}$, $40^{\circ} \mathrm{C}$ temperature, 60 minutes incubation time, and $50 \mathrm{rpm}$ agitation.

\section{Authors' Contributions}

TVP and GN developed the theory and performed the computations. TVP verified the analytical methods and AKK supervised the findings of this study. All authors discussed the results and equally contributed to the final manuscript.

\section{Conflict of Interest Disclosures}

The authors declare they have no conflicts of interest.

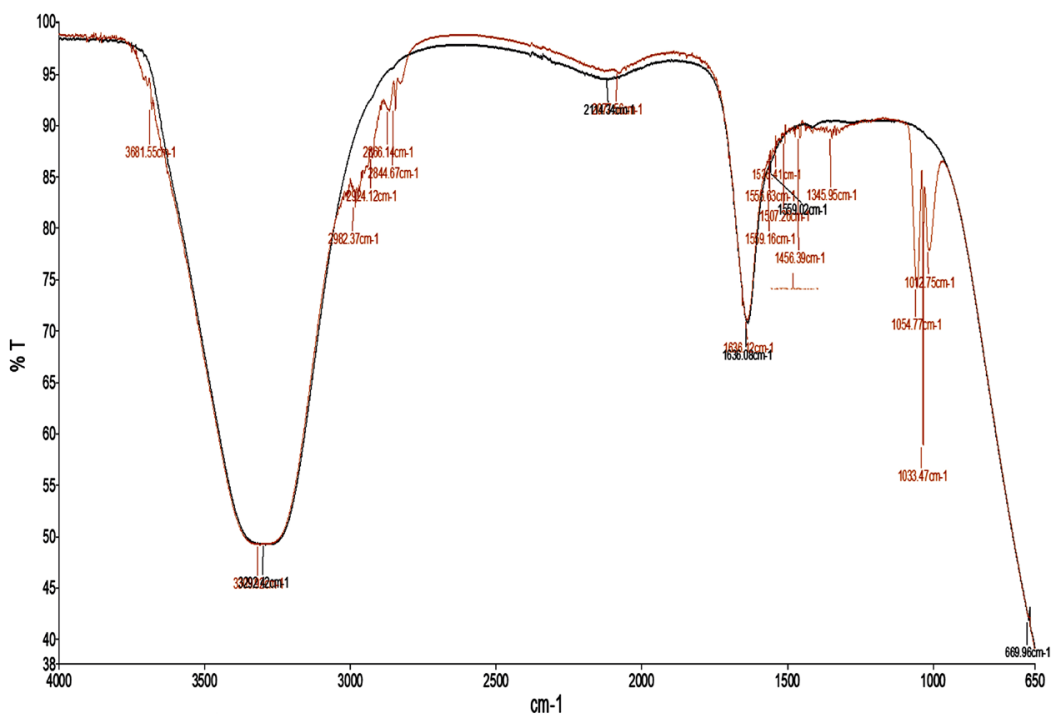

Figure 3. FT-IR Before and After. 
Acknowledgments

The authors would like to thank the Vels Institute of Science, Technology and Advance Studies and also the Sathyabama Institute of Science and technology for all their support in order to carry out this study.

\section{References}

1. Ghosh B, Saha R, Bhattacharya D, Mukhopadhyay M. Laccase and its source of sustainability in an enzymatic biofuel cell. Bioresour Technol Rep. 2019;6:268-278. doi:10.1016/j.biteb.2019.03.013.

2. Zhang H, Zhang S, He F, Qin X, Zhang X, Yang Y. Characterization of a manganese peroxidase from white-rot fungus Trametes sp.48424 with strong ability of degrading different types of dyes and polycyclic aromatic hydrocarbons. J Hazard Mater. 2016;320:265-277. doi:10.1016/j.jhazmat.2016.07.065.

3. Nihei R, Usami M, Taguchi T, Amachi S. Role of fungal laccase in iodide oxidation in soils. J Environ Radioact. 2018;189:127-134. doi:10.1016/j.jenvrad.2018.03.016.

4. Giacobbe S, Pezzella C, Lettera V, Sannia G, Piscitelli A. Laccase pretreatment for agrofood wastes valorization. Bioresour Technol. 2018;265:59-65. doi:10.1016/j.biortech.2018.05.108.

5. Ntougias $S$, Baldrian $P$, Ehaliotis $C$, et al. Biodegradation and detoxification of olive mill wastewater by selected strains of the mushroom genera Ganoderma and Pleurotus. Chemosphere. 2012;88(5):620-626. doi:10.1016/j.chemosphere.2012.03.042.

6. Gurav AA, Ghosh JS, Kulkarni GS. Decolorization of anthroquinone based dye Vat Red 10 by Pseudomonas desmolyticum NCIM 2112 and Galactomyces geotrichum MTCC 1360. Int J Biotechnol Mol Biol Res 2011;2(6):93-97.

7. Legerská B, Chmelová D2, Ondrejovič M. Decolourization and detoxification of monoazo dyes by laccase from the whiterot fungus Trametes versicolor. J Biotechnol. 2018;285:84-90. doi:10.1016/j.jbiotec.2018.08.011.

8. Afreen $\mathrm{S}$, Anwer $\mathrm{R}$, Singh RK, Fatma T. Extracellular laccase production and its optimization from Arthrospira maxima catalyzed decolorization of synthetic dyes. Saudi J Biol Sci. 2018;25(7):1446-1453. doi:10.1016/j.sjbs.2016.01.015.

9. Arunkumar T, Alex Anand D, Narendrakumar G. Production and partial purification of laccase from Pseudomonas aeruginosa ADN04. J Pure Appl Microbiol. 2014;8(2):727-731.

10. Senthivelan T, Kanagaraj J, Panda RC, Narayani T. Screening and production of a potential extracellular fungal laccase from Penicillium chrysogenum: Media optimization by response surface methodology (RSM) and central composite rotatable design (CCRD). Biotechnol Rep (Amst). 2019;23:e00344. doi:10.1016/j. btre.2019.e00344.

11. Bagewadi ZK, Mulla SI, Ninnekar HZ. Purification and immobilization of laccase from Trichoderma harzianum strain HZN10 and its application in dye decolorization. J Genet Eng Biotechnol.2017;15(1):139-150. doi:10.1016/j.jgeb.2017.01.007.

12. Othman AM, Elsayed MA, Elshafei AM, Hassan MM. Application of central composite design as a strategy to maximize the productivity of Agaricus bisporus CU13 laccase and its application in dye decolorization. Biocatalysis and Agricultural Biotechnology. 2018;14:72-79. doi:10.1016/j.bcab.2018.02.008.

13. Preethi TV, Kathireshan AK, Narendrakumar G. Optimization of media components for the production of laccase from Pleurotus ostreatus PKN 04 using response surface methodology. Pharm Lett. 216;8(9):33-40.

14. Preethi TV, Kathireshan AK, Narendrakumar G. Instrumental Analysis on Optimization of Laccase Production from Pleurotus ostreatus strain PKN 04 in Different Substrate by Solid State Fermentation (SSF). Res J Pharm Technol. 2018;11(2):657-660. doi:10.5958/0974-360X.2018.00123.3.

15. Arunkumar T, Alex Anand D, Narendrakumar G. Application of response surface methodology RSM-CCD for the production of laccases using submerged fermentation. Int J Pharma Bio Sci. 214;5(4):429-438

16. Arunkumar T, Alex Anand D, Narendrakumar G. Phylogenetic analysis of the internal transcribed spacer (ITS) region in laccase producing Pseudomonas aeruginosa ADN04 by predicted rRNA secondary structure. Biosci Biotech Res Asia. 2014;11(3):1573-
1579. doi:10.13005/bbra/1555

17. Prabu D, Parthiban R, Narendrakumar G. Application of response surface methodology for removal of Congo red dye by nanozerovalent iron impregnated cashew nut shell. J Chem Pharm Res. 2015;7(3):879-884.

18. Rezaei S, Tahmasbi H, Mogharabi M, et al. Laccase-catalyzed decolorization and detoxification of Acid Blue 92: statistical optimization, microtoxicity, kinetics, and energetics. J Environ Health Sci Eng. 2015;13:31. doi:10.1186/s40201-015-0183-1.

19. Tan L, Ning S, Zhang X, Shi S. Aerobic decolorization and degradation of azo dyes by growing cells of a newly isolated yeast Candida tropicalis TL-F1. Bioresour Technol. 2013;138:307-313. doi:10.1016/j.biortech.2013.03.183.

20. Nam S, Renganathan V. Non-enzymatic reduction of azo dyes by NADH. Chemosphere. 2000;40(4):351-357. doi:10.1016/S00456535(99)00226-X

21. Khouni I, Marrot B, Ben Amar R. Decolourization of the reconstituted dye bath effluent by commercial laccase treatment: Optimization through response surface methodology. Chem Eng J. 2010;156(1):121-133. doi:10.1016/j.cej.2009.10.007.

22. Daassi D, Zouari-Mechichi H, Frikha F, Martinez MJ, Nasri M, Mechichi T. Decolorization of the azo dye Acid Orange 51 by laccase produced in solid culture of a newly isolated Trametes trogii strain. 3 Biotech. 2013;3(2):115-125. doi:10.1007/s13205012-0076-2.

23. Baldrian P. Fungal laccases - occurrence and properties. FEMS Microbiol Rev. 2006;30(2):215-242. doi:10.1111/j.15744976.2005.00010.x.

24. Guan ZB, Song CM, Zhang N, et al. Overexpression, characterization, and dye-decolorizing ability of a thermostable, $\mathrm{pH}$-stable, and organic solvent-tolerant laccase from Bacillus pumilus W3. J Mol Catal B Enzym. 2014;101:1-6. doi:10.1016/j. molcatb.2013.11.009

25. Palmieri G, Cennamo G, Sannia G. Remazol Brilliant Blue R decolourisation by the fungus Pleurotus ostreatus and its oxidative enzymatic system. Enzyme Microb Technol. 2005;36(1):17-24. doi:10.1016/j.enzmictec.2004.03.026.

26. Kunamneni A, Ballesteros A, Plou FJ, Alcalde M. Fungal laccase-a versatile enzyme for biotechnological applications. In: Méndez Vilas, ed. Communicating current research and educational topics and trends in applied microbiology. Formatex; 2007:233-245.

27. Bourbonnais R, Paice MG. Oxidation of non-phenolic substrates. An expanded role for laccase in lignin biodegradation. FEBS Lett. 1990;267(1):99-102. doi:10.1016/0014-5793(90)80298-w.

28. Preethi TV, Kathireshan AK, Narendrakumar G. Statistical optimization of cultural parameters influencing laccase production by Pleurotus ostreatus PKN 04 using response surface methodology. J Chem Pharm Res. 2016;8(7):576-584.

29. Li K, Xu F, Eriksson KEL. Comparison of fungal laccases and redox mediators in oxidation of a nonphenolic lignin model compound. Appl Environ Microbiol. 1999;65(6):2654-2660.

30. Patel H, Gupte S, Gahlout M, Gupte A. Purification and characterization of an extracellular laccase from solid-state culture of Pleurotus ostreatus HP-1. 3 Biotech. 2014;4(1):77-84. doi:10.1007/s13205-013-0129-1.

31. Singh Arora D, Kumar Sharma R. Ligninolytic fungal laccases and their biotechnological applications. Appl Biochem Biotechnol. 2010;160(6):1760-1788. doi:10.1007/s12010-009-8676-y.

32. Kanagaraj J, Senthilvelan T, Panda RC. Biodegradation of azo dyes in industrial effluent: an eco-friendly way toward green technology. Clean Technol Environ Policy. 2015;17(2):331-341. doi:10.1007/ s10098-014-0783-y.

33. Viswanath B, Rajesh B, Janardhan A, Kumar AP, Narasimha G. Fungal laccases and their applications in bioremediation. Enzyme Res. 2014;2014:163242. doi:10.1155/2014/163242.

34. Dubé E, Shareck F, Hurtubise $Y$, Daneault C, Beauregard M. Homologous cloning, expression, and characterisation of a laccase from Streptomyces coelicolor and enzymatic decolourisation of an indigo dye. Appl Microbiol Biotechnol. 2008;79(4):597-603. doi:10.1007/s00253-008-1475-5. 